\title{
Hubungan kadar asam lemak dengan fungsi hati pada remaja obes
}

\author{
${ }^{1}$ Eca D. Y. Pasaribu \\ ${ }^{2}$ Sarah M. Warouw \\ ${ }^{2}$ Novie H. Rampengan
}

\author{
${ }^{1}$ Kandidat Skripsi Fakultas Kedokteran Universitas Sam Ratulangi Manado \\ ${ }^{2}$ Bagian/SMF Ilmu Kesehatan Anak Fakultas Kedokteran \\ Universitas Sam Ratulangi Manado \\ Email: ecadaray@gmail.com
}

\begin{abstract}
Obesity has reached epidemic proportion globally. Obesity is the risk factors to various diseases and early death. Being obese in adolescents is highly risky to become obese in adults and potentially have metabolic diseases and degenerative diseases later. Early detection of the changes in liver function is crucial in obese adolescents. The prevelation of non-alcoholic fatty liver disease increase simultaneously as the increase of the number of obesity in children and adolescents. This study was aimed to obtain the correlation of fatty acid level and liver function in obese adolescents. This was an observational study with a cross sectional design. Population was male and female obese students aged 13-15 years in Tomohon. Anthopometry value, trygliceride level, and the serum marker of liver function (AST and ALT) were examined. The respondents fasted for 10 to 12 hours before the blood examination. There were 39 obese adolescents as samples. The result of the Pearson Correlation test showed a positive correlation between trygliceride level and AST level but not statistically significant $(\mathrm{r}=0.048, \mathrm{p}=0.772)$ and a positive correlation between trygliceride level and ALT level but not statistically significant $(\mathrm{r}=0.068, \mathrm{p}=0.679)$. Conclusion: There was a positive correlation between the fatty acid level and the liver function in obese adolescents, however, it was not statistically significant.
\end{abstract}

Keywords: obesity, adolescents, trygliceride, AST, ALT

\begin{abstract}
Obesitas telah mencapai proporsi epidemik global. Obesitas merupakan predisposisi terhadap penyakit dan kematian dini akibat berbagai penyakit. Obesitas pada masa anak berisiko tinggi menjadi obesitas di masa dewasa dan berpotensi mengalami berbagai penyakit metabolik dan penyakit degeneratif di kemudian hari. Deteksi dini adanya perubahan fungsi hati penting dilakukan pada anak obes. Prevalensi penyakit perlemakan hati non alkoholik meningkat bersamaan dengan meningkatnya obesitas pada anak dan remaja. Penelitian ini bertujuan untuk mengetahui hubungan kadar asam lemak dan fungsi hati pada remaja obes. Jenis penelitian ialah observasional analitik dengan desain potong lintang. Populasi ialah siswa-siswi remaja obes berusia 13-15 tahun di Kota Tomohon. Dilakukan pengukuran antopometri, pemeriksaan trigliserida, dan serum penanda fungsi hati (AST dan ALT). Sampel penelitian berjumlah 39 remaja obes. Hasil uji korelasi Pearson menunjukkan hubungan positif antara kadar trigliserida dengan kadar AST namun tidak bermakna secara statistik $(\mathrm{r}=0,048, \mathrm{p}=0,772)$ dan terdapat pula hubungan positif antara kadar trigliserida dengan ALT namun tidak bermakna secara statistik $(\mathrm{r}=0,068, \mathrm{p}=0,679)$. Simpulan: Terdapat hubungan positif antara kadar asam lemak dengan fungsi hati pada remaja obes namun tidak bermakna secara statistik.
\end{abstract}

Kata kunci: obesitas, remaja, trigliserida, AST, ALT 
Obesitas merupakan masalah kesehatan dunia yang semakin sering ditemukan di berbagai negara. World Health Organization (WHO) menyatakan obesitas telah mencapai proporsi epidemik global, dengan sedikitnya 2,8 juta orang meninggal setiap tahun sebagai akibat kelebihan berat badan atau obesitas. ${ }^{1}$ Tidak hanya pada dewasa, obesitas juga dapat terjadi pada anak dan remaja. Prevalensi overweight dan obes pada anak di dunia meningkat dari 4,2\% di tahun 1990 menjadi 6,7\% di tahun 2010, dan diperkirakan akan mencapai $9,1 \%$ di tahun $2020 .^{2}$

Obesitas merupakan predisposisi terhadap penyakit dan kematian dini akibat berbagai penyakit. Terdapat $65 \%$ dari populasi dunia yang tinggal di perkotaan dimana overweight dan obesitas membunuh lebih banyak orang daripada mereka yang gizi kurang. Secara global, $44 \%$ menderita diabetes, $23 \%$ penyakit jantung iskemik, dan 33\% mengalami kanker yang berhubungan dengan obesitas. ${ }^{2}$

Lebih dari $30 \%$ remaja obesitas memenuhi kriteria sindroma metabolik. ${ }^{3}$ Mexitalia $\mathrm{M} \mathrm{dkk^{8 }}$ mendapatkan perbedaan bermakna pada antropometri dan profil lipid antara kedua kelompok. Rerata profil lipid terutama pada obesitas berada di atas nilai normal. Secara individual prevalensi faktor risiko peningkatan kadar trigliserida pada anak obes adalah sebesar $45,6 \% .^{3}$

Aminotransferase, berupa aspartate aminotransferase (AST) dan alanine aminotransferase (ALT), merupakan enzim penanda adanya cedera hepatosit. Pemeriksaan kadar serum aminotransferase merupakan pemeriksaan yang paling sering dilakukan terutama pada skrining kerusakan hepatoselular. Abnormalitas uji fungsi hati ini tidak dapat diabaikan karena mencerminkan bahwa telah terjadi suatu disfungsi hati walaupun asimptomatis. ${ }^{4}$

Deteksi dini adanya perubahan fungsi hati penting pada anak obes. Prevalensi Penyakit Perlemakan Hati Non-Alkoholik (PPHNA) meningkat bersamaan dengan meningkatnya obesitas pada anak dan remaja. ${ }^{5}$ PPNH ditemukan pada $40 \%$ anak gemuk melalui skrining USG hati. ${ }^{1}$
NAFLD saat ini merupakan salah satu penyebab utama penyakit hati kronik pada anak. $^{6}$ Seperempat anak dengan obesitas disertai dengan peningkatan serum aminotransferase, yaitu ALT dan AST. Peningkatan ALT lebih mencerminkan penyakit PPHNA dibandingkan penyakit hati kronis. ${ }^{7}$

Penelitian yang dilakukan oleh Eldrian et al. ${ }^{4}$ di Padang, pada 43 siswa SMA, menggambarkan peningkatan serum aminotransferase pada anak obes. Pada semua subyek penelitian, perbandingan kadar serum aminotransferasse mendapatkan nilai rerata kadar serum ALT lebih tinggi dibandingkan dengan AST. Perbandingan kadar serum aminotransferase pada kelompok PPNHA dengan bukan PPNHA didapatkan 39 orang remaja obesitas dengan PPNHA yang terdiri atas $12,8 \%$ memiliki kadar serum AST yang meningkat dan 28,2\% memiliki kadar serum ALT yang meningkat.

Pencegahan dan penanggulangan perlu dilakukan sedini mungkin mulai dari usia muda. Obesitas pada masa anak berisiko tinggi menjadi obesitas di masa dewasa dan berpotensi mengalami berbagai penyakit metabolik dan penyakit degeneratif di kemudian hari. ${ }^{1}$

\section{METODE PENELITIAN}

Jenis penelitian ini ialah observasional analitik dengan desain potong lintang. Penelitian ini dilaksanakan pada bulan September sampai November 2016 di Kota Tomohon.

Populasi penelitian ialah siswa-siswi remaja berusia 13 sampai 15 tahun yang memenuhi kriteria inklusi dan kriteria ekslusi. Kriteria inklusi ialah murid lakilaki dan perempuan yang tercatat dalam register sekolah, telah mendapat persetujuan dari orang tua murid untuk mengikuti penelitian, dan murid yang tergolong dalam kriteria obesitas. Kriteria ekslusi ialah murid yang sakit atau dalam pegobatan yang dapat mempengaruhi kadar asam lemak dan fungsi hati, dan murid yang tidak bersedia untuk menjadi sampel penelitian 
Jumlah sampel diperoleh dengan menggunakan rumus analitik korelatif yaitu sebanyak minimal 38 anak $(\alpha=0,05$, power $=80 \%$, dan $\mathrm{r}=0,4)$. Teknik pengambil sampel pada penelitian ini nonprobability sampling dengan teknik consecutive sampling.

Asam lemak yang dimaksud dalam penelitian ini ialah asam lemak bebas, dikategorikan normal jika nilainya $<200 \mathrm{mg} / \mathrm{dL}$. Fungsi hati dinilai berdasarkan kadar AST dan ALT yang merupakan penanda integritas hepatosit. AST dikategorikan normal pada remaja laki-laki dan perempuan bila nilainya $<29$ IU/L, sedangkan kadar ALT pada remaja laki-laki dan perempuan dikategorikan normal bila nilainya $<24$ IU/L.

Dilakukan pengukuran antopometri untuk menentukan kriteria obesitas pada responden. Setiap responden yang memenuhi kriteria inklusi dan ekslusi dianjurkan untuk puasa selama sepuluh sampai dua belas jam sebelum pengambilan darah.

Data diolah berdasarkan variabel penelitian dengan menggunakan SPSS. Data tersebut dihitung dan disajikan dalam bentuk teks dan tabel, kemudian dianalisis secara statistik menggunakan uji korelasi Pearson untuk mengetahui hubungan kadar asam lemak (trigliserida) dengan fungsi hati (AST dan ALT), nilai signifikan yang digunakan ialah $\mathrm{p}<0,05$.

\section{HASIL PENELITIAN}

Pada hasil penelitian didapatkan 39 anak yang memenuhi kriteria inklusi dan kriteria ekslusi dari SMP Stella Maris 13 orang (33,3\%), SMPN 1 Tomohon 11 orang $(28,2 \%)$, SMK Kristen 2 Tomohon 10 orang $(25,7 \%)$, SMA Kristen 2 BinsusTomohon 5 orang $(12,8 \%)$.

Berdasarkan Tabel 1 dapat dilihat karakteristik sampel penelitian yaitu lakilaki berjumlah 20 responden $(51,3 \%)$ dan perempuan berjumlah 19 responden $(48,7 \%)$ dengan usia 13 tahun berjumlah 15 responden $(38,5 \%)$, umur 14 tahun berjumlah 16 responden (41\%), dan umur 15 tahun berjumlah 8 responden $(20,5 \%)$.
Tabel 1. Karakteristik Sampel Penelitian

\begin{tabular}{lcc}
\hline \multicolumn{1}{c}{ Karakteristik } & n & \% \\
\hline Jenis kelamin & & \\
- Laki-laki & 20 & 51,3 \\
- Perempuan & 19 & 48,7 \\
\hline Usia & & \\
- 13 tahun & 15 & 38,5 \\
- 14 tahun & 16 & 41 \\
- 15 tahun & 8 & 20,5 \\
Total & 39 & 100 \\
\hline
\end{tabular}

Berdasarkan Tabel 2 dapat dilihat bahwa sebagian besar responden laki-laki mempunyai kadar trigliserida dengan kategori normal dengan jumlah 19 responden $(95 \%)$ dan kategori tidak normal dengan jumlah 1 responden (5\%), sama dengan yang ditemukan pada perempuan yaitu sebagian besar responden perempuan mempunyai kadar trigliserida dengan kategori normal dengan jumlah 18 responden $(94,7 \%)$ dan kategori tidak normal dengan jumlah 1 responden $(5,3 \%)$.

Tabel 2. Kadar trigliserida berdasarkan jenis kelamin

\begin{tabular}{lccc}
\hline $\begin{array}{c}\text { Jenis } \\
\text { kelamin }\end{array}$ & n & $\begin{array}{c}\text { Normal } \\
(\%)\end{array}$ & $\begin{array}{c}\text { Tidak } \\
\text { normal } \\
(\%)\end{array}$ \\
\hline Laki-laki & 20 & $19(95)$ & $1(5)$ \\
Perempuan & 19 & $18(94,7)$ & $1(5,3)$ \\
Total & 39 & 37 & 2 \\
\hline
\end{tabular}

Berdasarkan Tabel 3 dapat dilihat bahwa sebagian besar responden laki-laki mempunyai nilai fungsi hati AST dengan kategori tidak normal dengan jumlah 17 responden (85\%) dan kategori normal dengan jumlah 3 responden (15\%). Didapatkan sebagian besar responden perempuan mempunyai nilai fungsi hati AST dengan kategori tidak normal dengan jumlah 15 responden $(78,9 \%)$ dan kategori normal dengan jumlah 4 responden $(21,1 \%)$.

Berdasarkan Tabel 4 dapat dilihat kadar ALT berdasarkan jenis kelamin. sebagian besar responden laki-laki mempunyai nilai fungsi hati ALT dengan kategori tidak normal dengan jumlah 15 responden $(75 \%)$ dan kategori normal 
dengan jumlah 5 responden (25\%). Sebagian besar responden perempuan mempunyai nilai fungsi hati ALT dengan kategori tidak normal dengan jumlah 11 responden $(57,9 \%)$ dan kategori normal dengan jumlah 8 responden $(42,1 \%)$.

Tabel 3. Kadar AST berdasarkan jenis kelamin

\begin{tabular}{lccc}
\hline $\begin{array}{c}\text { Jenis } \\
\text { kelamin }\end{array}$ & n & $\begin{array}{c}\text { Normal } \\
(\%)\end{array}$ & $\begin{array}{c}\text { Tidak } \\
\text { normal } \\
(\%)\end{array}$ \\
\hline Laki-laki & 20 & $3(15)$ & $17(85)$ \\
Perempuan & 19 & $4(21,1)$ & $15(78,9)$ \\
Total & 39 & 7 & 32 \\
\hline
\end{tabular}

Tabel 4. Kadar ALT berdasarkan jenis kelamin

\begin{tabular}{lccc}
\hline $\begin{array}{c}\text { Jenis } \\
\text { kelamin }\end{array}$ & n & $\begin{array}{c}\text { Normal } \\
(\%)\end{array}$ & $\begin{array}{c}\text { Tidak } \\
\text { normal } \\
(\%)\end{array}$ \\
\hline Laki-laki & 20 & $5(25)$ & $15(75)$ \\
Perempuan & 19 & $8(42,1)$ & $11(57,9)$ \\
Total & 39 & 7 & 32 \\
\hline
\end{tabular}

Berdasarkan Tabel 5 dapat dilihat bahwa rerata variabel trigliserida responden $85,51 \mathrm{mg} / \mathrm{dL}$, nilai SD 56,203, nilai minimum $34 \mathrm{mg} / \mathrm{dL}$ dan nilai masimum 311 $\mathrm{mg} / \mathrm{dL}$. Rerata variabel AST responden 32,21 U/L, nilai SD 6,502, nilai minimum $22 \mathrm{U} / \mathrm{L}$, dan nilai masimum $58 \mathrm{U} / \mathrm{L}$. Rerata variabel ALT responden 27,46 U/L, nilai SD 9,364, nilai minimum $15 \mathrm{U} / \mathrm{L}$ dan nilai masimum $62 \mathrm{U} / \mathrm{L}$.

Tabel 5. Nilai Mean, SD, Minimum, Maksimum

\begin{tabular}{ccccc}
\hline & Mean & SD & Min & Maks \\
\hline Trigliserida & 85,51 & 56,203 & 34 & 311 \\
AST & 32,21 & 6,502 & 22 & 58 \\
ALT & 27,46 & 9,364 & 15 & 62 \\
\hline
\end{tabular}

Tabel 6 menjelaskan bahwa hasil uji statistik dengan menggunakan Pearson Correlation diperoleh hubungan trigliserida dengan AST mempunyai nilai koefisien 0,048 dan nilai signifikan sebesar 0,772 . Nilai koefisien 0,048 menandakan terdapat hubungan positif antara kadar trigliserida dengan AST. Pada anak dengan peningkatan kadar trigliserida, terdapat juga peningkatan pada kadar AST. Diperoleh juga hubungan trigliserida dengan ALT mempunyai nilai koefisien 0,068 dan nilai signifikan sebesar 0,679. Nilai koefisien 0,068 menandakan terdapat hubungan positif antara kadar trigliserida dengan ALT. Pada anak dengan peningkatan kadar trigliserida, terdapat juga peningkatan pada kadar ALT.

Tabel 6. Hubungan Kadar Asam Lemak dengan Fungsi Hati AST dan ALT

\begin{tabular}{ccc}
\hline Variabel & $\mathbf{r}$ & $\mathbf{p}$ \\
\hline Trigliserida - AST & 0,048 & 0,772 \\
Trigliserida - ALT & 0,068 & 0,679 \\
\hline
\end{tabular}

\section{BAHASAN}

Penelitian ini dilakukan pada siswa dan siswi remaja dengan rentang usia 13 sampai 15 tahun di Kota Tomohon dengan jumlah populasi sebanyak 112 anak. Sampel akhir didapatkan 39 anak yang diambil menggunakan metode consecutive sampling yaitu pengambilan sampel hingga memenuhi total jumlah sampel yang dibutuhan dan sesuai dengan kriteria inklusi dan ekslusi.

Dari hasil uji korelasi Pearson terhadap hubungan antara kadar asam lemak trigliserida dengan penanda fungsi hati AST dengan nilai $\mathrm{r}=0,048$ dan nilai $\mathrm{p}=$ 0,772. Dari hasil tersebut dinyatakan bahwa terdapat hubungan positif antara kadar trigliserida dengan AST namun secara statistik tidak bermakna $(\mathrm{r}=0,048, \mathrm{p}=$ 0,772). Kemudian dari hasil uji korelasi Pearson terhadap hubungan antara kadar asam lemak trigliserida dengan penanda fungsi hati ALT diperoleh nilai $r=0,068$ dan nilai $\mathrm{p}=0,679$. Dari hasil tersebut dinyatakan bahwa terdapat hubungan positif antara kadar trigliserida dengan ALT namun secara statistik tidak bermakna $(r=0,068, p=0,679)$.

Hal ini sejalan dengan penelitianpenelitian sebelumnya. Penelitian yang dilakukan oleh Nauman et al. ${ }^{8}$ menyatakan tidak terdapatnya hubungan antara peningkatan serum trigliserida dengan 
peningkatan kadar AST ( $\mathrm{p}=0,711$, IK95\%). Dari hasil uji chi-square juga didapatkan tidak terdapatnya hubungan antara peningkatan serum trigliserida dengan peningkatan kadar ALT ( $\mathrm{p}=0,348$, IK95\%).

Tidak terdapat perbedaan yang signifikan pada distribusi responden obes berdasarkan jenis kelamin yaitu $51,3 \%$ laki-laki obes dan 48,7\% perempuan obes. Hal ini berbeda dengan penelitian di Kota Tomohon pada tahun 2010, prevalensi obesitas sebesar $35 \%$ yang terdiri dari $31 \%$ perempuan dan $4 \%$ laki-laki ${ }^{9}$. Terbatasnya jumlah sampel yang bersedia berpartisipasi dalam penelitian ini mempengaruhi hasil dari penelitian.

Terdapat 32 responden (82\%) mempunyai kadar AST yang tidak normal dan 26 responden $(66,7 \%)$ mempunyai kadar ALT yang tidak normal. Dari seluruh responden yang mempunyai nilai penanda fungsi hati yang tidak normal, didapapatkan peningkatan enzim ini sebanyak kurang dari tiga kali normal. Kadar aminotransferase dapat meningkat ringan (1-3 kali normal) pada pankreatitis, perlemakan hati, sirosis Laennec, inflitrasi granulomatosa atau neoplastic, dan sirosis biliaris ${ }^{10}$. Jika rasio AST/ALT $\leq 1$, maka penyebab utamanya adalah cedera hepatosit. Sedangkan jika rasio AST/ALT $>1$ maka kemungkinan penyebabnya adalah penyakit hati alkoholik, cedera hati druginduced, keganasan, sirosis atau penyakit non-hati ${ }^{10}$.

Apabila hepatosit mengalami cedera, enzim penanda fungsi hati yang secara normal berada di intrasel ini masuk ke dalam aliran darah dan mengakibatkan peningkatn enzim penanda fungsi hati pada pemeriksaan laboratorium. Berbagai faktor dapat meningkatkan enzim penanda fungsi hati, dapat berasal dari hati maupun nonhati ${ }^{10}$.

Asam lemak bebas di dalam hati dapat terikat dengan trigliserida atau mengalami oksidasi di mitokondria, peroksisom atau mikrosom. Produk-produk hasil oksidasi sifatnya berbahaya dan dapat menyebabkan cedera pada hati yang selanjutnya dapat berlanjut menjadi fibrosis. Peroksidasi lipid dan stres oksidatif meningkatkan produksi hidroksineonenal (HNE) dan malondialdehid (MDA) yang meningkatkan fibrosis hati melalui aktivasi oleh sel stelata yang menyebabkan peningkatan produksi transforming growth factor-beta (TGF- $\beta)^{11}$.

Dari 39 sampel remaja obes, hanya ditemukan 2 responden yang mempunyai nilai trigliserida yang tidak normal. Ratarata nilai trigliserida dalam penelitian ini adalah $85,51 \mathrm{mg} / \mathrm{dL}$ dan nilai standard deviasi 56,203. Penemuan ini lebih rendah dibandingkan dengan penelitian oleh Mexitalia $^{3}$ pada 57 remaja obes laki-laki yaitu rata-rata $122,6 \mathrm{mg} / \mathrm{dL}$ dengan standard deviasi 57,5 dan 22 remaja obes perempuan yaitu rata-rata $115 \mathrm{mg} / \mathrm{dL}$ dengan standard deviasi 38,5.

Banyak faktor yang menyebkan rendahnya jumlah sampel yang memiliki kadar trigliserida tinggi. Beberapa anak tinggal di asrama, dengan pola makan yang sudah diatur dan kegiatan fisik yang lebih tinggi. Beberapa anak juga didapati sedang dalam program penurunan berat badan. Hal ini sangat memengaruhi hasil penelitian.

Pada penelitian ini ditemukan 17 anak dengan kategori AST tidak normal pada remaja laki-laki (85\%) dan 15 anak pada remaja perempuan $(78,9 \%)$ dengan ratarata keseluruhan nilai AST 32,2 U/L dan standard deviasi 6,502. Penemuan ini lebih tinggi dibandingkan dengan penelitian sebelumnya di Padang ${ }^{4}$ yaitu ditemukan 5 anak yang mengalami pengingkatan kadar AST (12\%) dengan rata-rata nilai AST 20,6 U/L dan standard deviasi 10,59.10

Penelitian ini mendapatkan 15 anak dengan kategori ALT tidak normal pada remaja laki-laki $(75 \%)$ dan 11 anak pada remaja perempuan $(57,9 \%)$ dengan ratarata keseluruhan nilai ALT 27,64 U/L dan standard deviasi 9,364. Penemuan ini lebih tinggi dibandingkan dengan penelitian sebelumnya ${ }^{4}$ yaitu ditemukan 11 anak yang mengalami pengingkatan kadar AST $(28,2 \%)$ dengan rata-rata nilai ALT 21,34 U/L dan standard deviasi 18,71.10

Pada penelitian ini, kebanyakan yang mengalami peningkatan kadar AST dan ALT adalah laki-laki. Laki-laki mempunyai 
risiko terjadinya perlemakan hati nonalkoholik. $^{12}$ Hal ini disebabkan laki-laki mempunyai kadar estrogen yang lebih rendah dibandingkan wanita. Estrogen (17 $\beta$-estradiol E2) berguna dalam proses proteksi fungsi hati. Pemberian estrogen pada tikus selama 15 hari terbukti dapat menurunkan nilai AST dan ALT. Estrogen meningkatkan aktivitas enzim GPx dan antioksidan plasma sehingga terjadi penurunan peroksidasi hepar. Di samping itu, estrogen juga dapat mengurangi kadar gula darah karena efek insulinotropiknya dengan menghambat ATP-sensitive potassium channels pada membrane sitoplasma sel $\beta$ pancreas. ${ }^{13}$

Penelitian yang dilakukan oleh Gemilang $\mathrm{B} \mathrm{dkk}^{14}$ pada 51 pasien perlemakan hati non alkoholik didapatkan 21 responden dengan nilai trigliserida tidak normal, dan didapatkan derajat hubungan yang kuat $(r=0,512)$ dan hubungan yang bermakna $(\mathrm{p}<0,001)$ antara kadar trigliserida dengan kadar ALT serum.

Berbeda dengan penelitian Gemilang B31, penelitian yang dilakukan oleh Eldrian $\mathrm{F} \mathrm{dkk}^{4}$ pada 43 remaja obes di Padang mendapatkan adanya hubungan kadar serum AST dengan derajat perlemakan hati non alkoholik secara statistik memiliki nilai $\mathrm{p}=0,45$ yang artinya tidak terdapat hubungan yang bermakna $(\mathrm{p}<0,05)$ dan adanya hubungan kadar serum ALT dengan derajat perlemakan hati secara statistik memiliki nilai $\mathrm{p}=0,22$ yang artinya tidak terdapat hubungan yang bermakna secara statistic.

Diagnosis perlemakan hati non alkoholik ditegakkan dengan dua komponen, yaitu adanya bukti perlemakan hati dan/atau steatohepatitis dan adanya eksklusi penyebab lain perlemakan hati, seperti alkoholisme ${ }^{11}$. Diagnosis pasti ditegakkan dengan biopsi hati, tetapi hal ini tidak mudah dilakukan. Risiko biopsi tidak sebanding dengan manfaat yang didapatkan. Pengukuran kadar ALT serum adalah modalitas skrining yang digunakan untuk diagnosis perlemakan hati non alkoholik secara presumtif pada banyak studi populasi. Meskipun cukup berguna untuk skrining, pengukuran kadar ALT serum ini tidak sempurna dalam hal sensitivitas dan spesifisitas ${ }^{11}$.

Berdasarkan penjelasan di atas, dapat diketahui sebab adanya hubungan positif namun secara statistic tidak bermakna antara kadar asam lemak dengan fungsi hati pada remaja obes. Kelemahan dari penelitian ini yaitu terbatasnya jumlah sampel penelitian.

\section{SIMPULAN}

Terdapat hubungan positif antara kadar asam lemak dengan fungsi hati AST dan ALT pada remaja obes namun tidak bermakna secara statistik.

\section{SARAN}

Disarankan untuk memberikan penyuluhan kepada masyarakat mengenai obesitas beserta dampak yang dapat diakibatkan, perbanyak aktifitas fisik, dan penyediaan menu makanan yang sehat pada anak dan mengurangi asupan makanan dengan kadar asam lemak yang tinggi. Anak dengan berat badan di atas $100 \mathrm{~kg}$ sebaiknya dikonsultasikan ke ahli gizi.

\section{DAFTAR PUSTAKA}

1. World Health Organization. 10 facts on obesity [Internet]. Switzerland. 2012. Available from : URL : http://www.who.int/features/factfiles/ obesity/en/

2. de Onis M, Blossner M, Borghi E. Global prevalence and trends of overweight and obesity among preschool children. Am J Clin Nutr. 2010;92:1257-64

3. Mexitalia M, Utari A, Sakundarno M, Yamauchi T, Subagio HW, Soemantri A. Sindrom metabolik pada remaja obesitas. M Med Indones. 2009;43:300-6.

4. Eldrian F, Jurnalis YD, Ali H, Bachtiar H, Rozetti. Hubungan kadar serum aminotransferase dengan derajat perlemakan hati pada remaja obesitas. Sari Pediatri. 2015;17(5):361-6

5. Nobili V, Baroni GS, Alisi A, Miele L, Valenti L, Vajro P. A 360-degree overview of paediatric NAFLD: 
Recent insights. J Hepatol. 2013;58:1218-29.

6. Bpac better medicine. Liver function testing in primary care. Dunedin: Bpac better medicine; 2007.

7. Vajro P, Franzese A, Valerio G, Iannucci MP, Nunzia A. Lack of e. ursodioxycholic acid for the tretment of liver abnormalities in obesitas children. J Pediatr 2000; 136:739-43

8. Nauman Y. Hubungan peningkatan serum trigliserida dengan peningkatan enzim aminotransferase pada penderita $\mathrm{dm}$ tipe 2 di rsup h. Adam malik medan tahun 2009 [Thesis] [Universitas sumatera utara medan], 2010

9. Kussoy DWK. Prevalensi hiperurisemia pada remaja obes di kota Tomohon [skripsi]. Fakultas Kedokteran Universitas Sam Ratulangi Manado; 2009

10. Sacher RA, McPherson RA. Tinjauan klinis hasil pemeriksaan laboratorium. Ed 11. Jakarta: EGC; 2004.h.360-84

11. Nurman A, Huang M. Perlemakan hati non alkoholik. Universa Medicina. Vol 26, 2007

12. Qureshi IZ, Shabana A, Fareeha. Effect of overweight and obesity on liver function in a sample from pakistani population. Pakistan J. Zool., vol. 38(1), pp. 49-54, 2006

13. Ahmed MA, Hassanein KM. Effects of estrogen on hyperglycemia and liver dysfunction in diabetic male rats. Int $\mathbf{J}$ Physiol Pharmacol 2012;4(3):156-66

14. Gemilang B, Yanwirasti, Miro S. Hubungan Kadar Trigliserida dan Kolesterol-HDL Terhadap Kadar Alanine Aminotransferase pada Pasien Non Alcoholic Fatty Liver Disease. Jurnal Kesehatan Andalas. 2016; 5(1) 